\title{
Congenital muscular dystrophy, Ullrich type
}

INSERM

\section{Source}

INSERM. (1999). Orphanet: an online rare disease and orphan drug data base. Congenital muscular dystrophy, Ullrich type. ORPHA:75840

Ullrich cong enital muscular dystrophy (UCMD) is characterized by early-onset, generalized and slowly prog ressive muscle weakness, multiple proximal joint contractures, marked hypermobility of the distal joints and normal intelligence. 